Ежемесячный анализ динамики и структуры указанных выше отклонений позволил оценить уровень производственных потерь сырья и предпринять стимулирующие мероприятия для их минимизации.

В течение 2009 г. был проведен ряд мероприятий, которые позволили снизить уровень производственных потерь. Была произведена инвентаризация весового хозяйства с заменой оборудования в местах использования наиболее дорогостоящего сырья, был проведен мониторинг технологического процесса, по результатам ежемесячного анализа потерь были организованы производственные совещания. Анализ производственных потерь за 2009 г. показал снижение этого показателя по всем видам используемого сырья, как в натуральном, так и в стоимостном выражении.

За 2009 г. после проведенных мероприятий в натуральном выражении излишки сырья составили всего 7 т, а в стоимостном - недостача сырья сократилась до 171 тыс. руб. Производственные потери в сравнении с 2008 г. в стоимостном выражении снизились более чем в 5 раз.

Таким образом, проведенные мероприятия в рамках политики, основанной на принципах ресурсосбережения и бережливого производства, существенно сократили затраты предприятия. Модернизация существующих технологий позволила снизить себестоимость продукции, а значит, получить более конкурентоспособный продукт, продукт с большей добавленной стоимостью. Разработанные технологии дали возможность сократить объем неликвидных материалов, что позволило уменьшить складс- кие расходы предприятия и освободить дополнительные складские площади. Вовлечение в производство отходов дало возможность высвободить дополнительный объем сырья и материалов, что достаточно важно в условиях ограниченности ресурсной базы.

\section{Список источников}

1. 65 лет КЗФ. Вчера, сегодня, завтра. Екатеринбург: Мастерская культурной рекламы, 2006. 80 c.

2. Акимов А. Итоги 2010 г. как задел на год нынешний // Металлоснабжение и сбыт. 2011. №2. С. 14-18.

3. Виньков А., Сиваков Д. Ферросплавы из Лимпопо // Эксперт. 2005. №33. С. 35-38.

4. Вумек Дж., Джонс Д. Бережливое производство. Как избавиться от потерь и добиться процветания вашей компании. М.: Альпина Бизнес Бук, 2008. 472 с.

5. Завязкин В., Некрасов В. Итого. Успокоения ждать не стоит. Российский рынок металлов. Итоги 2005 г. // Металлоснабжение и сбыт. 2006. №2. С. 10-21.

6. Интеграция науки, образования и производства стратегия развития инновационной экономики : материалы I Международной научно-практической конференции. Екатеринбург: Изд-во Урал. гос. экон. ун-та, 2011. Ч. 1. 232 с. (Секция 2. Интеграция науки и производства. Трансфер технологий).

7. Литти С. Бережливая производительность // Справочник по управлению персоналом. 2010. №9. С. 31-36.

8. Методические рекомендации по планированию, учету и калькулированию себестоимости продукции на предприятиях черной металлургии. М.: Центральный научно-исследовательский институт им. И. П. Бардина, Институт экономики, 1991. 151с.

9. Романова О. А., Ченчевич С. Г., Шешуков О. Ю. Особенности технологической модернизации металлургических предприятий региона в условиях мирового кризиса // Экономика региона 2009 №3 С. 54-61.

\section{УДК 338.45:332.142}

ключевые слова: ресурсосбережение, технологическая модернизация, бережливое производство, ферросплавы

\title{
RESOURCE-SAVING POLICY IN THE CONTEXT OF TECHNOLOGICAL UPDATING OF FERROALLOY PRODUCTION
}

The necessity of technological updating of ferroalloy production with resource-saving technologies as a basis for it is substantiated in the paper. Lean manufacturing as a tool to organize efficient management of material costs is considered. An algorithm to search for the ways of the company's production process enhancement has been developed; steps aimed at solving the resource-saving problems at JSC Klyuchevsky Ferro Alloy Plant are proposed. 


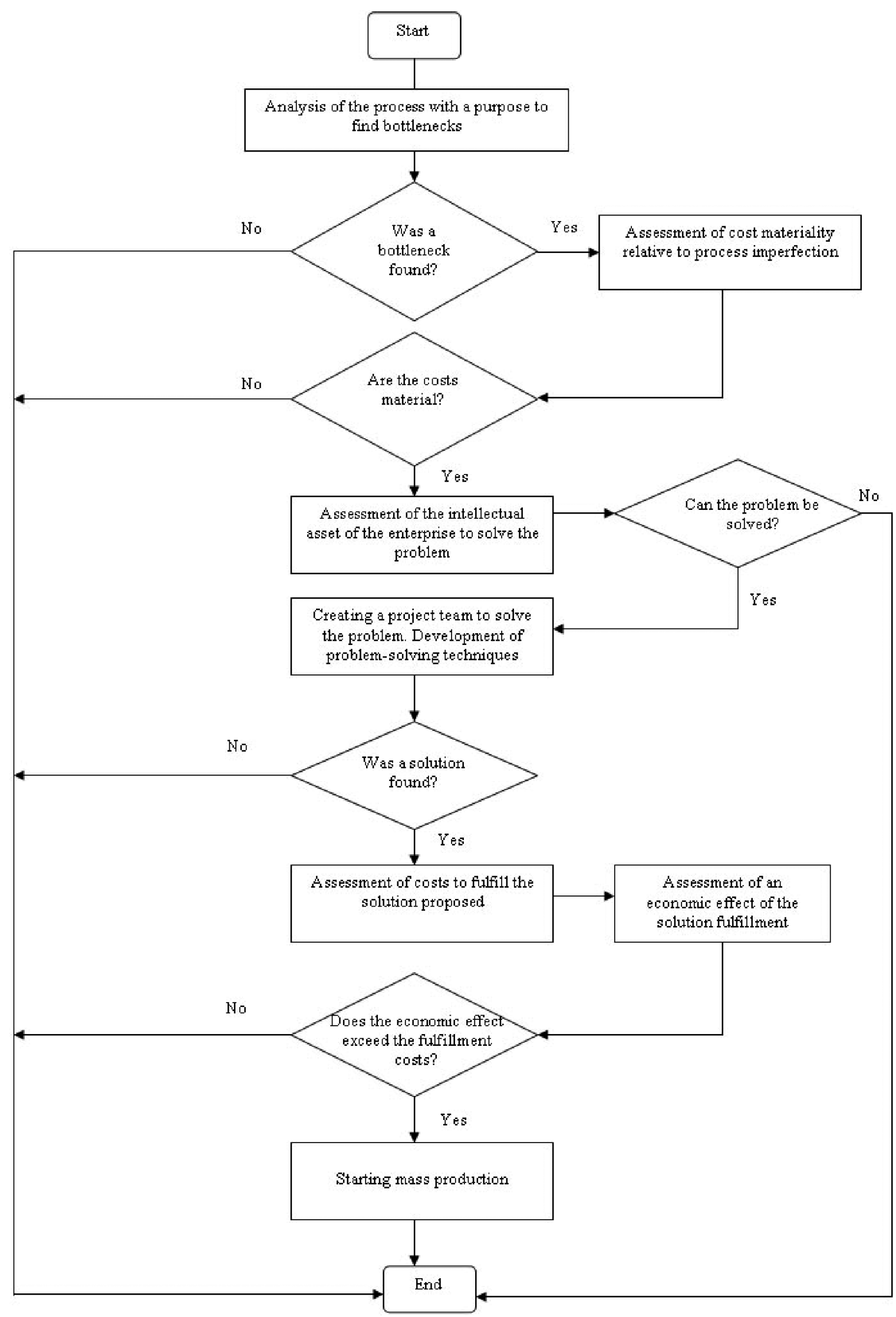

Fig. Search algorithm for operation improvement ways 
Metallurgy is one of the key Russian industries. Recovery of ironworks from the crisis is rather successful. A general development trend is updating. In 2010 enterprises began to resume suspended projects in order to increase marketability. Currently, one of the key objectives for metallurgists is to improve product quality and high process stage speedup [1, p.15-16]. The given task is feasible only providing a focus laid on production of high-quality steel alloys, which are impossible to be produced without the use of ferroalloys. Therefore, the matter of development of ferroalloy subindustry of ferrous metallurgy assumes increasing significance.

Nine special-purpose enterprises produce ferroalloy products in Russia. Three of them (CHEMC, Kuznetsk Ferroalloys, Serov Ferro-alloy Plant) produce $85 \%$ of the total Russian ferroalloy melt [2, p. 13]. Russian ferroalloy subindustry is represented by differently-oriented plants. There are such ferroalloy plants which produce a range of 2-3 types of alloys, each of them being produced in hundreds of thousands tons. Other plants are oriented on production of a wide range of low-tonnage ferroalloys and addition alloys. JSC Klyuchevsky Ferro Alloy Plant is among such enterprises. The company produces over 40 standard alloys and about 20 alloys are under exploratory development. The main products by the company are aluminothermic metal chromium, low-carbon ferrochromium, ferrotitanium and clinker products.

The key objective relative to the regional metallurgical sector development in the near and long term in the context of implementation of the innovation scenario of economic growth in Russia is industry modernization aimed at wide use of resource-saving technologies, priority development of high-technology industries, enhancement of the output quality of metallurgy products and development of new types $[3$, p. 57]. Material capacity of the metallurgical sector enterprises is rather high. Thus, the material costs of production at the Klyuchevsky Ferroalloy Plant are about $91 \%$ of the total production cost on the average. The company policy is thus based on solving the problems of resource-saving under such high material capacity of production and according to the innovation scenario of economic growth in Russia.

Economic management of material costs is possible by way of the lean technology tools. The Leanconcept is aimed at maximizing the human potential, identifying and eliminating hidden loss in the processes on the basis of continuous involvement of the staff in the process improvement. In the course of the Lean-project implementation at enterprises, it was demonstrated that fulfillment of the specified requirements may result in labour productivity raising at least four times as much, and cutting production costs by a few percent, increasing thus competitiveness of the enterprise [4, p. 21-23].

Lean manufacturing is focused on enhancement of production process by way of rational use of labor resources, material resources, machinery and equipment, industrial areas, reduction of the time required for engineering setup, production processes with a focus on the consumer needs [5, p. 33]. In order to achieve an appreciable effect, sophisticated lean-technologies should not necessarily be used; a systemic analysis of the value creation flow, exploring «bottlenecks» and maximizing the focus on improvement of a specific workflow suffice $[6$, p. 31, 34].

Summarizing the lean manufacturing approaches and taking into account the technological specifics, an algorithm was generated to find the ways of operation improvement (fig.).

When considering the production process at JSC Klyuchevsky Ferro Alloy Plant, we have identified several areas requiring optimization: generation of industrial waste, illiquid products and substantial production losses. Activities within the framework of the resource-saving policy and lean manufacturing principles are executed in several ways, according to the problems specified. The activities include introduction of resource-saving technologies and upgrading particular engineering processes.

1. Utilization of resource-saving technologies

1.1. Introduction of resource-saving technologies assuming recycling illiquid products.

The structure of ferroalloy and addition alloy production for 2007-2009 is represented as follows: metal chromium in the production output structure (in physical terms) amounts to $22 \%$ in 2007-2009 at an average; ferrochromium $-30 \%$; ferrotitanium $-12 \%$; clinker products - $33 \%$; other ferroalloys and addition alloys, powder wire, bricks $-3 \%$.

The above-mentioned production pattern varied considerably during the period in question (20072009) due to change in demand for a certain type of ferroalloys on the market. Thus, in 2007 peak demand for ferrotitanium in the last five years was observed, the largest share in the output amounted to over $20 \%$, and annual production reached 8.2 thousand tons. The bulk ferrotitanium was exported, and one of the customers' requirements was a ferrotitanium fraction 
of 5-50 mm. respectively, 0-5 $\mathrm{mm}$ ferrotitanium fractions were sifted when preparing export products. There was continual accumulation of siftings along with a rather high level of export sales.

Disposal of such fine ferrotitanium represents a great challenge; sales of siftings were moderate with a substantial discount and sometimes even below the cost price. Amount of the siftings was considerable by the end of 2007 - up to 100 tons, and that caused significant expenses for storage of the mentioned product.

An objective to analyze if development of a technology for illiquid product processing (ferrotitanium siftings) is possible was set before the technical department of the plant headed by the chief metallurgist. The given objective was solved at a pilot site. The new technology assumed replacement of a part of the raw material appropriated for smelting by ferrotitanium siftings. Involvement of the fine ferrotitanium in the production is in essence recycling of the initial set of raw materials. That contributes to cutting down the expenses for the recycled raw materials due to the fact that some of the components are appropriated as siftings.

Introduction of the developed technology into mass production has solved several problems. First, illiquid fine ferrotitanium was used up, which resulted in reduction of storage costs and clearing extra areas. By the beginning of the second half of 2008 the bulk of the siftings in stock was processed. Second, the use of ferrotitanium siftings for smelting reduced the cost of ferrotitanium, so far as the amount of other expensive mixture components was decreased. The cost value of ferrotitanium produced by way of the sifting processing technology appeared $11 \%$ lower as compared to the basic technology of ferrotitanium production. A total of $45 \%$ of the cumulative production of ferrotitanium was produced applying the new technology in 2008 .

1.2. Introduction of resource-saving technologies assuming technological waste use

Production activity entails generation of waste. In this case, waste is referred to as a part of raw materials, semi-products and basic materials to be processed, which lost in quality of initial materials completely or partially under processing (physical properties, chemical properties, part of inherent elements, etc.) [7, p. 61]. Certain types of waste can be recycled.

Remelting is one of the waste types at the enterprise considered. The given category includes waste generated in the process of cleaning and packing of a metal block, substandard metal produced after clinker sorting, metal with a basic substance generated in the process of preparation of a melting unit for the ferroalloy smelting campaign. Remelting products appear mostly as a result of ferrochromium production out of the basic products at JSC Klyuchevsky Ferro Alloy Plant. Ferrochromium remelting products amount up to $0.4 \%$ of the ferrochromium production. Recycling remelting products is virtually reclamation of raw materials; it reduces consumption of referring raw materials going into production. Thus, in case if remelting products go into production, several challenges are met:

1) Cutting of production costs becomes possible due to the fact that the use of basic raw materials is reduced along with the use of remelting products. Cutting of ferrochromium production costs per year on the average owing to the use of remelting products amounted to $1.4 \%$ or 2.9 million rubles in money terms (for ferrochromium production using remelting).

2) Storage costs are reduced owing to the lack of remelting product storage expenses.

3) Consumption of raw materials is reduced (they are partially replaced by remelting products), which is substantial in the context of the scantiness of resources.

Consumption of the basic raw materials (chromium ore and aluminum) was reduced by $1.5 \%$ and $1.2 \%$ respectively, which in physical terms amounted to 88 and 18 tons per year respectively. The given amount of raw materials will suffice to produce extra commodity output of ferrochromium for 5.6 million rubles. However, the use of remelting products in production is beneficial to a certain extent. The metallurgists of the plant correlated the weight of metal block (the outcome, in essence) and the volume of remelting specified. Notably, the waste used for production requires preliminary analysis of its structure and an extent of influence on the course of the production process, as well as on the result of the production activity. Such an analysis was executed at JSC Klyuchevsky Ferro Alloy Plant, and an optimum amount of remelting consumption was determined, which allowed saving the material resource of remelting and retain a positive effect of the use of waste for production.

2. Updating of particular technological processes

Another problem discovered when using the algorithm developed is substantial production losses. Significant deviations were detected when compar- 
ing the end month inventory data relative to raw materials to the raw material balance data estimated on the basis of the smelting register. The given deviations occurred as a result of balance errors, spillage, and human factor. On an aggregate, 29-ton excess of raw materials in physical terms, and 1-million ruble shortage of raw materials in value terms were observed regarding all the types of basic raw materials over 2008. Such a situation is due to the fact that negative deviation (shortage) was observed relative to more expensive types of raw materials, and positive deviation (surplus) - to less expensive. A monthly analysis of the dynamics and structure of the above-mentioned deviations allowed evaluating raw material production losses extent and stimulating minimization of the given losses.

A number of steps had been taken to reduce production losses extent over 2009. Inventory of weighing equipment was taken, and the equipment in the areas with the most expensive raw material utilization was replaced; monitoring of the production process was made; production meetings were held by the results of the monthly analysis of the losses. The analysis of the production losses over 2009 demonstrated reduction of the rate regarding all the types of raw materials used both in physical and value terms. The measures taken resulted in only 7-tons surplus of raw materials in physical terms, and the shortage of raw materials was reduced to 171 thousand rubles in value terms. Production losses decreased over five times as much in value terms as compared to 2008 .

Thus, the activities in the context of the lean manufacturing policy reduced significantly the expenditures of the enterprise. Updating of the exist- ing technologies allowed reducing production costs, and hence obtaining a more competitive product, the product with a higher value added. The technologies developed have made it possible to reduce the non-liquid material extent, and that was ground to reduce storage costs and clear extra storage areas. Recycling the waste allowed releasing extra volume of raw materials, which is vital in the context of scanty resources.

\section{References}

1. Akimov, A. (2011). 2010 results as a groundwork for the current year. Metallosnabzhenie i Sbit (Metal Supply and Sales), 2. p.14-18;

2. Zavyazkin, V., Nekrasov, V. (2006). Total. Appeasement is not worth waiting for. (The Russian market of metals: results of 2005). Metallosnabzhenie i Sbit (Metal Supply and Sales), 2. p. 10-21;

3. Romanova, O. A., Chenchevich, S. G., Sheshukov, O. Y. (2009). Specifics of technological updating of metallurgical enterprises of the region under the global crisis. Economy of Region, 3, p. 54-61;

4. Integration of science, education and industry - the innovation economy development strategy: materialsof the I International Scientific and Practical Conference. Ekaterinburg: the Ural State University of Economics Publ., 2011. Section 2. Integration of science and industry. Technology transfer, Part 1. $232 \mathrm{p}$.

5. Womack, J., Jones, D. (2008). Lean manufacturing: how to avoid losses and secure prosperity of the company. Moscow: Alpina Business Book Publ. 472 p.

6. Litty, S. (2010). Lean productivity. Personnel Management Reference Book, 9. p. 31-36;

7. Methodical recommendations on planning, accounting and calculation of production costs at ironworks. Moscow: Central Research Institute named after I. P. Bardin. Institute of Economics, 1991.151p.

UDC: $338.45: 332.142$

keywords: resource-saving technology, technological updating, lean manufacturing, ferroalloys

\section{СИСТЕМНЫЙ ВЗГЛЯД НА ПРОБЛЕМУ ЭФФЕКТИВНОСТИ ФУНКЦИОНИРОВАНИЯ ПРЕДПРИЯТИЙ ХИМИЧЕСКОГО КОМПЛЕКСА РОССИИ}

\footnotetext{
Химическая промышленность как один из базовых комплексов народного хозяйства России играет важную роль в развитии отечественной экономики, закладывая основы ее долгосрочного и стабильного развития. Однако, как и большинство отраслей в России, сегодня химичес-
}

кая промышленность переживает сложный период. Наличие комплекса общих экономических проблем и внутренних проблем управления обуславливает стремительный рост неконкурентоспособности российской химической продукиии на мировом рынке. Если не принять меры по 